\title{
Estimation of Vessel Passage through Bosphorus
}

\author{
Alp Küçükosmanoğlu ${ }^{a}$, Özen Arlı Küçükosmanoğlu ${ }^{b^{*}}$ \\ ${ }^{a, b}$ Burdur Mehmet Akif Ersoy University, Faculty of Engineering and Architecture, Department of Civil Engineering, \\ Burdur 15030, Turkey \\ E-mail address: $\underline{\text { akucukosmanoglu@,mehmetakif.edu.tr }}{ }^{\text {a }}, \underline{\text { okucukosmanoglu@mehmetakif.edu.tr }}^{\mathrm{b}^{*}}$
}

ORCID numbers of authors: 0000-0002-7551-1513 ${ }^{a}, 0000-0002-2119-8074^{b}$

Received date: 21.06 .2021

Accepted date: 16.07.2021

\begin{abstract}
The Bosphorus is a heritage from the past to the present with its natural, historical and cultural features. Vessels passing through the Bosphorus, which is a narrow waterway, create a risk in Istanbul Strait. Thousands of vessels carrying dangerous cargoes pass through the Bosphorus every year. In this study, the changes in the cargos carried by these vessels and number of vessels over years are examined. It is seen that approximately 44000 vessels per year have passed through considering the last decade. The data of Ministry of Transport and Infrastructure, General Directorate of Marine between the years 1995 and 2020 has been used to estimate the change of the number of the vessels for five years period. Although the estimation show that the vessels numbers will decrease with an estimation of $\sim 32,250$ vessels for the year 2025, the total gross tonnage will increase in the future years. The results show that, while the number of bulk carrier vessels, livestock carriers, passenger ships and refrigerated cargo carriers will increase, the number of general cargo vessels will decrease in the future years.
\end{abstract}

Keywords: Bosphorus, Istanbul Strait, Estimation, Vessels Number, Maritime Traffic.

\section{Introduction}

Istanbul, where Asia and Europe continents meet, has an intense maritime traffic in the Bosphorus, which is a narrow waterway between the Black Sea and the Marmara open through Mediterranean and international waters. Approximately 48,000 vessels/year passed through the Bosphorus according to the data of Ministry of Transport and Infrastructure, General Directorate of Marine between the years 1995 and 2020 as shown in Table 1 [1, 2], besides the local maritime traffic of the region. There are around 2000 scheduled ship traffic daily only in the southern part of the Istanbul Strait [3]. As can be seen from numbers, Bosphorus has a busy maritime traffic. Especially in the last decade many researchers study maritime safety and risk assessment for the region. The main subject is accident statistics and risk assessment over all the studies [4-8]. There are passage schedule and navigation management researches for reducing the maritime risk of this busy region [9-11]. Uğurlu et al. [12] studied economic loss of marine accidents of the region. Therefore, in order to reduce the maritime accidents and enhance the navigation safety, General Directorate of Coastal Safety and related institutions do research and give couple of services in the region. 
Table 1. Number of vessels passing through Bosphorus

\begin{tabular}{cccccccc}
\hline Years & $\begin{array}{c}\text { Number } \\
\text { of } \\
\text { Vessels }\end{array}$ & Years & $\begin{array}{c}\text { Number } \\
\text { of } \\
\text { Vessels }\end{array}$ & $\begin{array}{c}\text { Total } \\
\text { Gross } \\
\text { Tonnage }\end{array}$ & Years & $\begin{array}{c}\text { Number } \\
\text { of } \\
\text { Vessels }\end{array}$ & $\begin{array}{c}\text { Total } \\
\text { Gross } \\
\text { Tonnage }\end{array}$ \\
\hline 1995 & 46,954 & 2004 & 54,564 & - & 2013 & 46,532 & $551,771,780$ \\
1996 & 49,952 & 2005 & 54,794 & - & 2014 & 45,529 & $582,468,334$ \\
1997 & 50,942 & 2006 & 54,880 & $475,796,880$ & 2015 & 43,544 & $565,216,784$ \\
1998 & 49,304 & 2007 & 56,606 & $484,867,696$ & 2016 & 42,553 & $565,282,287$ \\
1999 & 47,906 & 2008 & 54,396 & $513,639,614$ & 2017 & 42,978 & $599,324,748$ \\
2000 & 48,079 & 2009 & 51,422 & $514,656,446$ & 2018 & 41,103 & $613,088,166$ \\
2001 & 42,637 & 2010 & 50,871 & $505,615,881$ & 2019 & 41,112 & $638,892,062$ \\
2002 & 47,283 & 2011 & 49,798 & $523,543,509$ & 2020 & 38,404 & $619,758,776$ \\
2003 & 46,939 & 2012 & 48,329 & $550,526,579$ & & & \\
\hline
\end{tabular}

Vessels can request pilot (through Bosphorus) to increase the safety of passage. Average $\sim 53.5 \%$ of the passed vessels have requested pilot between the years 2006 and 2020 according to the data of Ministry of Transport and Infrastructure, General Directorate of Marine. Number of passed vessels have been archived on 6 categories in the data. The categories are according to vessel lengths, as shorter than $100 \mathrm{~m}$, between 100-150 m, between 150-200 m, between 200$250 \mathrm{~m}$, between $250-300 \mathrm{~m}$, longer than $300 \mathrm{~m}$ as shown in Table 2 [2].

Table 2. Number of vessels passing through Bosphorus according to their length

\begin{tabular}{cccccccccc}
\hline Years & \multicolumn{7}{c}{ Number of Vessels } \\
\cline { 2 - 10 } & $\begin{array}{c}\text { Longer } \\
\text { than }\end{array}$ & $\begin{array}{c}\text { Btw. } \\
250-\end{array}$ & $\begin{array}{c}\text { Btw. } \\
200-\end{array}$ & $\begin{array}{c}\text { Btw. } \\
150-\end{array}$ & $\begin{array}{c}\text { Btw. } \\
100-\end{array}$ & $\begin{array}{c}\text { Shorter } \\
\text { than }\end{array}$ & Total & $\begin{array}{c}\text { Total } \\
\text { With }\end{array}$ & $\begin{array}{c}\text { Percentage } \\
\text { of Vessels }\end{array}$ \\
& $300 \mathrm{~m}$ & $300 \mathrm{~m}$ & $250 \mathrm{~m}$ & $200 \mathrm{~m}$ & $150 \mathrm{~m}$ & $100 \mathrm{~m}$ & & Pilot & with Pilot \\
\hline $\mathbf{2 0 0 6}$ & 0 & 957 & 2,696 & 7,216 & 22,427 & 21,584 & 54,880 & 26,589 & $48.45 \%$ \\
$\mathbf{2 0 0 7}$ & 25 & 1,114 & 2,514 & 6,840 & 23,889 & 22,224 & 56,606 & 26,685 & $47.14 \%$ \\
$\mathbf{2 0 0 8}$ & 25 & 1,256 & 2,630 & 7,931 & 22,050 & 20,504 & 54,396 & 27,001 & $49.64 \%$ \\
$\mathbf{2 0 0 9}$ & 8 & 1,051 & 2,812 & 8,256 & 20,683 & 18,612 & 51,422 & 24,977 & $48.57 \%$ \\
$\mathbf{2 0 1 0}$ & 6 & 1,216 & 2,401 & 7,881 & 20,990 & 18,377 & 50,871 & 26,035 & $51.18 \%$ \\
$\mathbf{2 0 1 1}$ & 6 & 1,283 & 2,511 & 8,419 & 20,176 & 17,403 & 49,798 & 26,011 & $52.23 \%$ \\
$\mathbf{2 0 1 2}$ & 14 & 1,285 & 2,567 & 9,278 & 18,976 & 16,209 & 48,329 & 24,812 & $51.34 \%$ \\
$\mathbf{2 0 1 3}$ & 14 & 1,268 & 2,519 & 9,307 & 18,341 & 15,083 & 46,532 & 24,023 & $51.63 \%$ \\
$\mathbf{2 0 1 4}$ & 2 & 1,364 & 2,929 & 10,154 & 16,734 & 14,346 & 45,529 & 24,508 & $53.83 \%$ \\
$\mathbf{2 0 1 5}$ & 0 & 1,283 & 2,647 & 10,235 & 16,178 & 13,201 & 43,544 & 23,349 & $53.62 \%$ \\
$\mathbf{2 0 1 6}$ & 0 & 1,143 & 2,730 & 10,363 & 16,077 & 12,240 & 42,553 & 22,356 & $52.54 \%$ \\
$\mathbf{2 0 1 7}$ & 5 & 1,318 & 2,682 & 10,965 & 16,101 & 11,907 & 42,978 & 24,059 & $55.98 \%$ \\
$\mathbf{2 0 1 8}$ & 3 & 1,377 & 2,726 & 11,640 & 14,466 & 10,891 & 41,103 & 23,565 & $57.33 \%$ \\
$\mathbf{2 0 1 9}$ & 0 & 1,324 & 3,076 & 11,873 & 15,497 & 9,342 & 41,112 & 26,632 & $64.78 \%$ \\
$\mathbf{2 0 2 0}$ & 2 & 1,299 & 3,651 & 10,592 & 14,441 & 8,419 & 38,404 & 24,754 & $64.46 \%$ \\
\hline
\end{tabular}

Almost all the passed vessels longer than $150 \mathrm{~m}$ length have requested pilot after the year 2019 . However, before the year 2018 almost all the passed vessels longer than $200 \mathrm{~m}$ length have requested pilot. Average $\sim 85.38 \%$ of passed vessels between $150-200 \mathrm{~m}$ length, average $\sim 44.91 \%$ of passed vessels between $100-150 \mathrm{~m}$ length and average $\sim 30.43 \%$ of passed vessels shorter than $100 \mathrm{~m}$ length have requested pilot between the years 2006 and 2020 . Where almost half of the passed vessels between 100-150 m length request pilot, only one third of the passed vessels shorter than $100 \mathrm{~m}$ requested pilot for that period (Fig. 1, Table 3). 


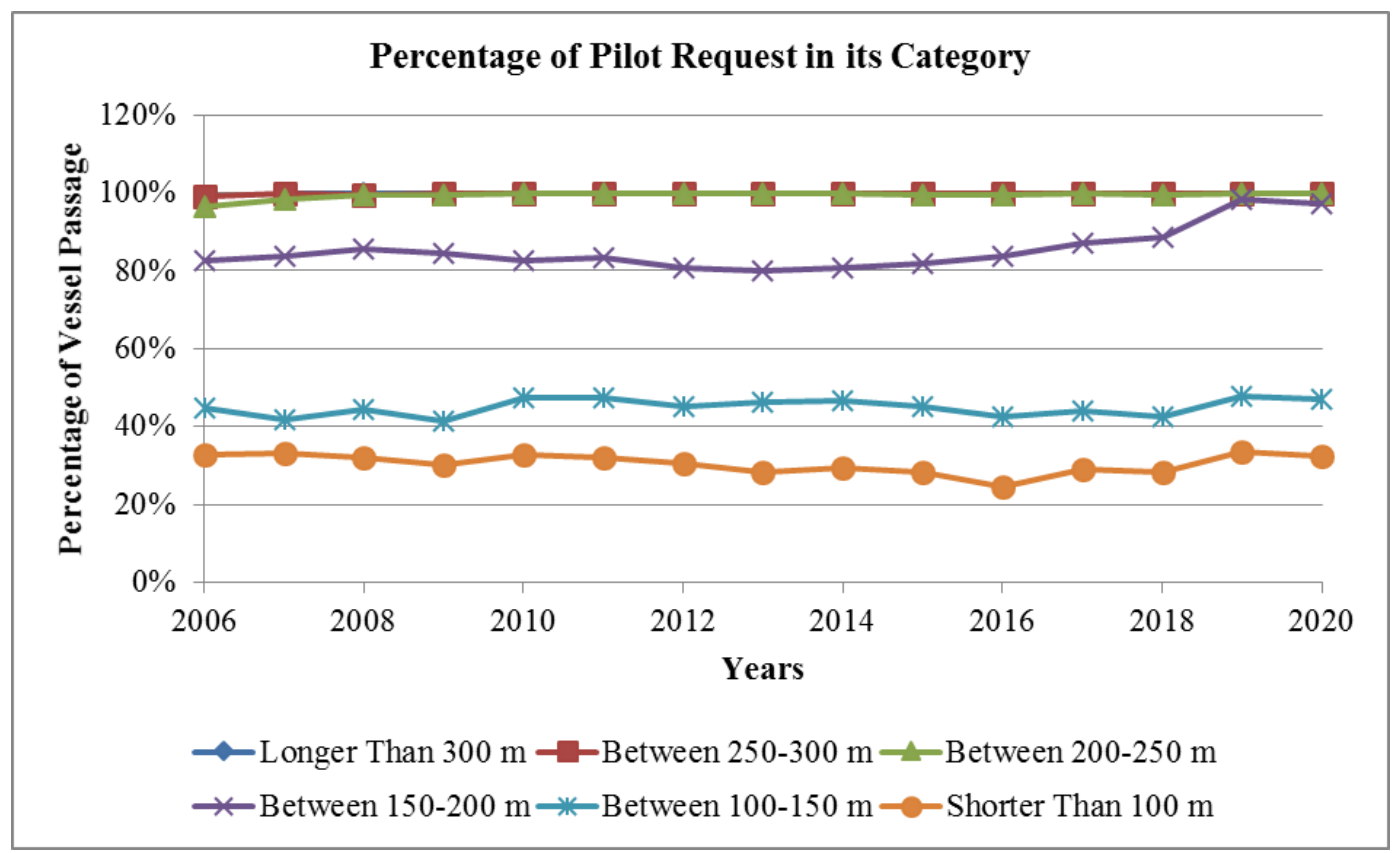

Fig. 1. Percentage of vessels passing through Bosphorus according to vessels length

Table 3. Percentage of vessels passing through Bosphorus with Pilot on vessels category

\begin{tabular}{|c|c|c|c|c|c|c|}
\hline \multirow[t]{2}{*}{ Years } & \multicolumn{6}{|c|}{ Percentage of Vessels with Pilot } \\
\hline & $\begin{array}{l}\text { Longer } \\
\text { than } \\
300 \mathrm{~m}\end{array}$ & $\begin{array}{l}\text { Btw. 250- } \\
300 \mathrm{~m}\end{array}$ & $\begin{array}{l}\text { Btw. 200- } \\
250 \mathrm{~m}\end{array}$ & $\begin{array}{l}\text { Btw. 150- } \\
200 \mathrm{~m}\end{array}$ & $\begin{array}{c}\text { Btw. 100- } \\
150 \mathrm{~m}\end{array}$ & $\begin{array}{c}\text { Shorter } \\
\text { than } \\
100 \mathrm{~m}\end{array}$ \\
\hline 2006 & & $99.06 \%$ & $96.48 \%$ & $82.44 \%$ & $44.70 \%$ & $32.74 \%$ \\
\hline 2007 & $100.00 \%$ & $99.64 \%$ & $98.49 \%$ & $83.76 \%$ & $41.84 \%$ & $33.07 \%$ \\
\hline 2008 & $100.00 \%$ & $99.60 \%$ & $99.28 \%$ & $85.74 \%$ & $44.39 \%$ & $31.82 \%$ \\
\hline 2009 & $100.00 \%$ & $99.90 \%$ & $99.40 \%$ & $84.50 \%$ & $41.45 \%$ & $29.95 \%$ \\
\hline 2010 & $100.00 \%$ & $100.00 \%$ & $100.00 \%$ & $82.60 \%$ & $47.17 \%$ & $32.65 \%$ \\
\hline 2011 & $100.00 \%$ & $100.00 \%$ & $100.00 \%$ & $83.45 \%$ & $47.51 \%$ & $32.18 \%$ \\
\hline 2012 & $100.00 \%$ & $100.00 \%$ & $99.65 \%$ & $80.63 \%$ & $45.03 \%$ & $30.42 \%$ \\
\hline 2013 & $100.00 \%$ & $100.00 \%$ & $99.84 \%$ & $80.05 \%$ & $46.38 \%$ & $28.31 \%$ \\
\hline 2014 & $100.00 \%$ & $100.00 \%$ & $99.86 \%$ & $80.83 \%$ & $46.49 \%$ & $29.49 \%$ \\
\hline 2015 & & $100.00 \%$ & $99.32 \%$ & $81.92 \%$ & $45.16 \%$ & $28.38 \%$ \\
\hline 2016 & & $100.00 \%$ & $99.45 \%$ & $83.56 \%$ & $42.47 \%$ & $24.60 \%$ \\
\hline 2017 & $100.00 \%$ & $99.92 \%$ & $99.96 \%$ & $87.23 \%$ & $43.80 \%$ & $28.87 \%$ \\
\hline 2018 & $100.00 \%$ & $99.85 \%$ & $99.34 \%$ & $88.43 \%$ & $42.36 \%$ & $28.08 \%$ \\
\hline 2019 & & $100.00 \%$ & $99.97 \%$ & $98.25 \%$ & $47.92 \%$ & $33.63 \%$ \\
\hline 2020 & $100.00 \%$ & $100.00 \%$ & $100.00 \%$ & $97.26 \%$ & $46.95 \%$ & $32.31 \%$ \\
\hline
\end{tabular}

When the percentage of passed vessel have been calculated according to the length categories for the year 2006; $39.33 \%$ of passed vessels are in the shorter than $100 \mathrm{~m}$ length category, 40.87 $\%$ of passed vessels are between $100-150 \mathrm{~m}, 13.15 \%$ of passed vessels are between $150-200 \mathrm{~m}$, $4.91 \%$ of passed vessels are between $200-250 \mathrm{~m}, 1.74 \%$ of passed vessels are between 250 $300 \mathrm{~m}$. However, for the year 2020, 21.92\% of passed vessels are in the category of shorter than $100 \mathrm{~m}$ length, $37.60 \%$ of passed vessels are between $100-150 \mathrm{~m}, 27.58 \%$ of passed vessels are between $150-200 \mathrm{~m}, 9.51 \%$ of passed vessels are between $200-250 \mathrm{~m}, 3.38 \%$ of passed vessels are between $250-300 \mathrm{~m}, 0.01 \%$ of passed vessels are longer than $300 \mathrm{~m}$ (Fig. 2). It can be seen from the graph comparing the years 2006 and 2020; that there is no considerable change for 
longer than $300 \mathrm{~m}$ length vessels and a slight decrease for the 100-150 m length vessels. However, the percentage of passed vessel doubled for 150-200 m length and 250-300 m length vessels. The percentage of passed vessel also doubled for the $200-250 \mathrm{~m}$ length vessels in the last few years comparing year 2006. Furthermore, the percentage of the passed vessels shorter than $100 \mathrm{~m}$ dropped to almost half. If the dominant percentage of the passed vessels generally evaluated, the vessels between 150-200 m length doubled, however the vessels shorter than $100 \mathrm{~m}$ dropped to almost half.

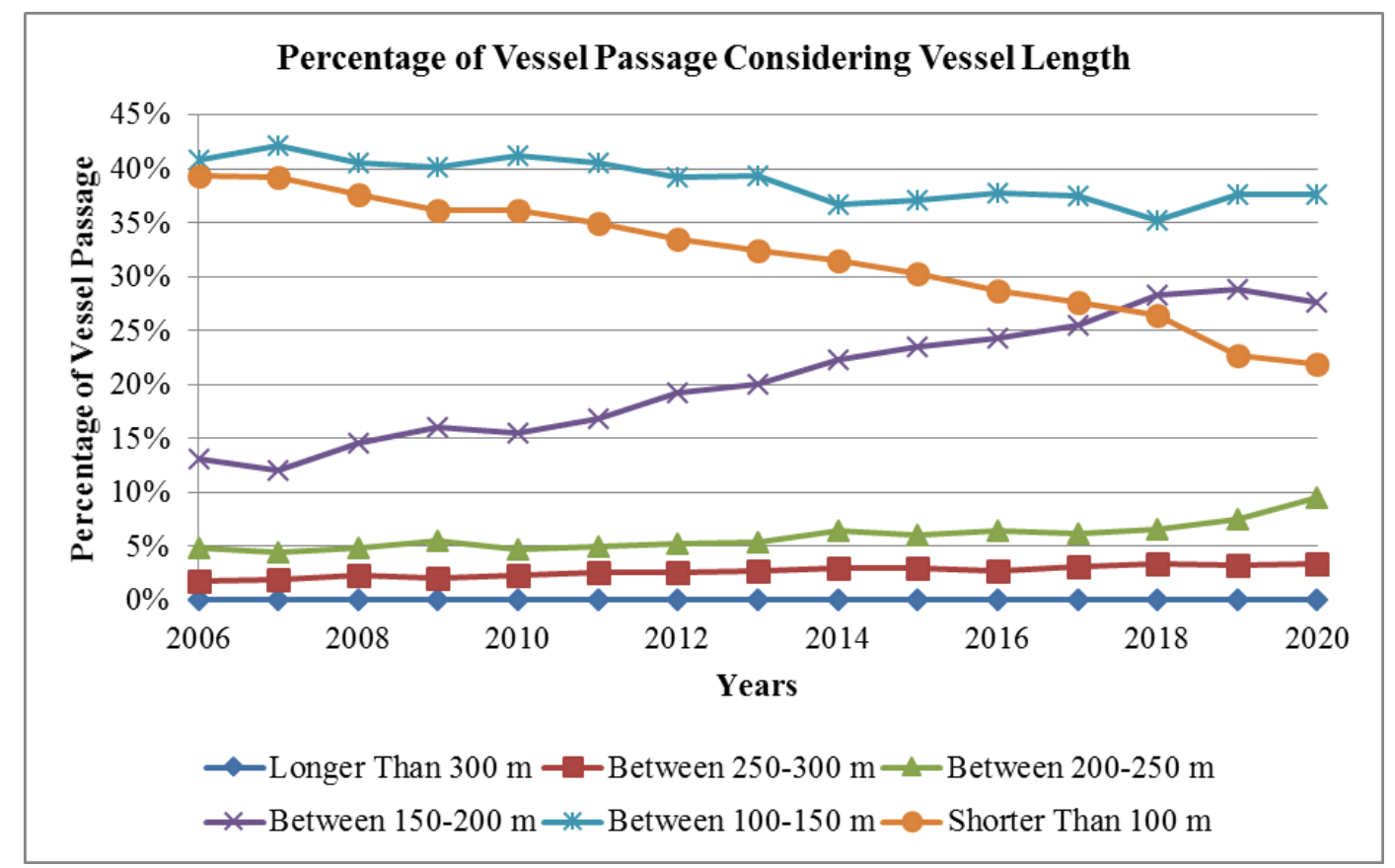

Fig. 2. Percentage of vessels passing through Bosphorus according to vessels length

Passed vessels through Bosphorus have been also archived between the years 2006 and 2020 according to their types. The data consists of 17 types of vessels: Barge / Barge Carrier; Bulk Carrier; Cement Carrier; Container Ship; Ferry; General Cargo Ship; Livestock Carrier; Naval; Passenger Ship; Refrigerated Cargo Carrier; Roll on Roll of Vessel; Other Tanker, TTA; Chemical Tanker, TCH; Liquefied Petroleum Gas/Natural Gas Tanker, LPG/LNG; Tug; Vehicle Carrier and Other (Table 4). 
Table 4. Number of vessels passing through Bosphorus according to vessels types

\begin{tabular}{|c|c|c|c|c|c|c|c|c|c|c|c|c|c|c|c|}
\hline & 2006 & 2007 & 2008 & 2009 & 2010 & 2011 & 2012 & 2013 & 2014 & 2015 & 2016 & 2017 & 2018 & 2019 & 2020 \\
\hline $\begin{array}{l}\text { Barge / Barge } \\
\text { Carrier }\end{array}$ & 63 & 47 & 52 & 53 & 28 & 17 & 2 & 19 & 12 & 17 & 6 & 18 & 3 & 9 & 15 \\
\hline Bulk Carrier & 5,419 & 5,145 & 5,978 & 6,635 & 5,863 & 6,341 & 7,163 & 6,898 & 7,263 & 7,485 & 7,664 & 8,206 & 8,501 & 8,811 & 8,592 \\
\hline $\begin{array}{l}\text { Cement } \\
\text { Carrier }\end{array}$ & 13 & 6 & & & 3 & 4 & 2 & 1 & 4 & 8 & 4 & 6 & 12 & 9 & 18 \\
\hline $\begin{array}{l}\text { Container } \\
\text { Ship }\end{array}$ & 2,401 & 2,727 & 2,773 & 2,014 & 2,292 & 2,718 & 2,707 & 2,868 & 3,073 & 2,664 & 2,734 & 2,659 & 2,561 & 2,642 & 2,633 \\
\hline Ferry & 4 & 1 & 1 & & 1 & 3 & 1 & 1 & 4 & 2 & 1 & 1 & 1 & 2 & 1 \\
\hline $\begin{array}{l}\text { General Cargo } \\
\text { Ship }\end{array}$ & 33,082 & 34,822 & 32,735 & 30,840 & 30,876 & 29,288 & 27,126 & 25,521 & 24,107 & 22,412 & 21,344 & 21,163 & 19,269 & 18,637 & 16,864 \\
\hline $\begin{array}{l}\text { Livestock } \\
\text { Carrier }\end{array}$ & 141 & 136 & 70 & 147 & 243 & 238 & 390 & 432 & 391 & 434 & 585 & 544 & 508 & 530 & 555 \\
\hline Naval & 168 & 166 & 200 & 180 & 114 & 94 & 129 & 196 & 237 & 318 & 342 & 237 & 176 & 178 & 205 \\
\hline $\begin{array}{l}\text { Passenger } \\
\text { Ship }\end{array}$ & 1,658 & 1,702 & 1,147 & 786 & 631 & 481 & 583 & 474 & 649 & 444 & 291 & 336 & 367 & 250 & 74 \\
\hline $\begin{array}{l}\text { Refrigerated } \\
\text { Cargo Carrier }\end{array}$ & 908 & 819 & 805 & 623 & 602 & 441 & 248 & 204 & 65 & 24 & 40 & 46 & 34 & 59 & 52 \\
\hline $\begin{array}{l}\text { Roll on Roll of } \\
\text { Vessel }\end{array}$ & 436 & 441 & 713 & 350 & 457 & 599 & 492 & 406 & 431 & 377 & 352 & 396 & 245 & 266 & 222 \\
\hline $\begin{array}{l}\text { Other Tanker, } \\
\text { TTA }\end{array}$ & 7,659 & 7,204 & 6,564 & 6,557 & 6,464 & 6,216 & 5,912 & 5,685 & 5,587 & 5,825 & 6,033 & 6,212 & 6,014 & 5,934 & 5,252 \\
\hline $\begin{array}{l}\text { Chemical } \\
\text { Tanker, TCH }\end{array}$ & 1,680 & 2,050 & 1,975 & 1,876 & 1,711 & 1,660 & 1,779 & 1,561 & 1,618 & 1,576 & 1,681 & 1,878 & 1,950 & 2,462 & 2,653 \\
\hline $\begin{array}{l}\text { Liquefied } \\
\text { Petroleum } \\
\text { Gas/Natural } \\
\text { Gas Tanker, } \\
\text { LPG/LNG }\end{array}$ & 814 & 800 & 764 & 866 & 1,099 & 1,227 & 1,336 & 1,760 & 1,540 & 1,232 & 989 & 742 & 623 & 561 & 530 \\
\hline Tug & 294 & 253 & 313 & 304 & 293 & 245 & 274 & 241 & 231 & 282 & 237 & 262 & 384 & 270 & 175 \\
\hline $\begin{array}{l}\text { Vehicle } \\
\text { Carrier }\end{array}$ & 14 & 92 & 189 & 78 & 42 & 47 & 37 & 47 & 93 & 17 & 16 & 45 & 88 & 113 & 87 \\
\hline Other & 126 & 195 & 117 & 113 & 152 & 179 & 148 & 218 & 224 & 427 & 234 & 227 & 367 & 379 & 476 \\
\hline Total & 54,880 & 56,606 & 54,396 & 51,422 & 50,871 & 49,798 & 48,329 & 46,532 & 45,529 & 43,544 & 42,553 & 42,978 & 41,103 & 41,112 & 38,404 \\
\hline
\end{tabular}




\section{Methodology}

Data can be examined via statistical methods. Regression analysis can be used to see the data change [13]. Generally, linear regression analysis is used to see the trend of the data. It is also possible to use other regression analysis to obtain more suitable regression lines. However, to see the trend and estimate the vessel passage roughly, linear regression analysis has been preferred in the study. Although polynomial regression analysis has been performed in the study, the results are not given for all trials.

\subsection{Linear regression analysis}

Linear regression is the simplest regression analysis can be applied to the data $\left(\mathrm{x}_{\mathrm{i}}, \mathrm{y}_{\mathrm{i}}\right)$. Mathematical expression of the regression line is shown in Eq. (1).

$$
y=a_{0}+a_{1} x
$$

To calculate slope $\left(a_{1}\right)$ Eq. (2) and to calculate constant $\left(a_{0}\right)$ Eq. (3) can be used, where $\mathrm{n}$ is the number of the data, $\bar{y}$ mean value of the data $\mathrm{y}, \bar{x}$ mean value of the data $\mathrm{x}$.

$$
\begin{gathered}
a_{1}=\frac{n \sum_{i=1}^{n} x_{i} y_{i}-\sum_{i=1}^{n} x_{i} \sum_{i=1}^{n} y_{i}}{n \sum_{i=1}^{n} x_{i}^{2}-\left(\sum_{i=1}^{n} x_{i}\right)^{2}} \\
a_{0}=\bar{y}-a_{1} \bar{x}
\end{gathered}
$$

Coefficient of determination $\left(R^{2}\right)$ in Eq. (4) is used to quantify the error of the regression line where $S_{t}$ is the total sum of the squares around the mean as shown in Eq. (5) and $S_{r}$ is the total sum of the squares of the residuals as shown in Eq. (6).

$$
\begin{gathered}
R^{2}=\frac{S_{t}-S_{r}}{S_{t}} \\
S_{t}=\sum_{i=1}^{n}\left(y_{i}-\bar{y}\right)^{2} \\
S_{r}=\sum_{i=1}^{n}\left(y_{i}-a_{0}-a_{1} x_{i}\right)^{2}
\end{gathered}
$$

Coefficient of determination of the model is the explanation percentage of the original uncertainty.

\subsection{Polynomial regression analysis}

A second order polynomial regression analysis can be also applied to the data $\left(\mathrm{x}_{\mathrm{i}}, \mathrm{y}_{\mathrm{i}}\right)$. Mathematical expression of the regression line is shown in Eq. (7).

$$
y=a_{0}+a_{1} x+a_{2} x^{2}
$$

The terms $\left(a_{0}, a_{1}, a_{2}\right)$ as shown in Eq. (8) can be solved with any method. To determine coefficient of determination $\left(R^{2}\right)$ Eq. (4) and Eq. (5) can be used. However $S_{r}$ the total sum of the squares of the residuals should be calculated using Eq. (9). 


$$
\begin{array}{ccc}
(n) a_{0}+\left(\sum_{i=1}^{n} x_{i}\right) a_{1}+\left(\sum_{i=1}^{n} x_{i}^{2}\right) a_{2} & = & \sum_{i=1}^{n} y_{i} \\
\left(\sum_{i=1}^{n} x_{i}\right) a_{0}+\left(\sum_{i=1}^{n} x_{i}^{2}\right) a_{1}+\left(\sum_{i=1}^{n} x_{i}^{3}\right) a_{2} & = & \sum_{i=1}^{n} x_{i} y_{i} \\
\left(\sum_{i=1}^{n} x_{i}^{2}\right) a_{0}+\left(\sum_{i=1}^{n} x_{i}^{3}\right) a_{1}+\left(\sum_{i=1}^{n} x_{i}^{4}\right) a_{2} & = & \sum_{i=1}^{n} x_{i}^{2} y_{i} \\
S_{r}=\sum_{i=1}^{n}\left(y_{i}-a_{0}-a_{1} x_{i}-a_{2} x_{i}^{2}\right)^{2} &
\end{array}
$$

\section{Application and Results}

The number of vessels passed through Bosphorus data (Table 1) have been analyzed by linear regression between the years 1995 and 2020 (Fig. 3). However the coefficient of determination $\left(R^{2}\right)$ the explanation of data is calculated an inadequate value as $24.85 \%$.

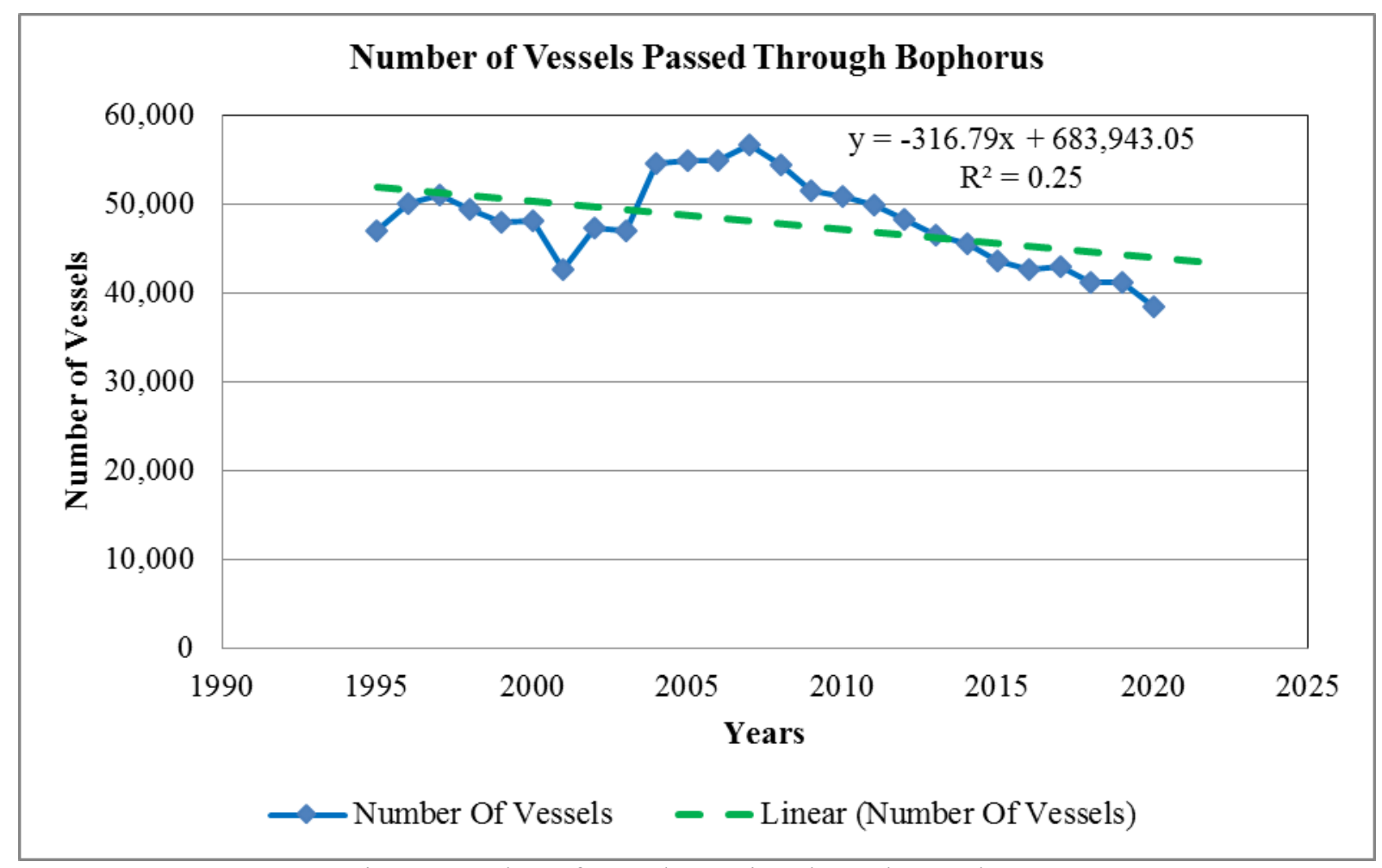

Fig. 3. Number of vessels passing through Bosphorus

Therefore, the data of number of vessels passed through Bosphorus have been reanalyzed by linear regression between the years 2006 and 2020 (Fig. 4). The coefficient of determination value is calculated as $97.38 \%$. Thus the linear regression line can be used to estimate forward 5 years period. The projected estimation gives 32,255 vessels will pass through Bosphorus in 2025 (Table 5).

Table 5. Estimation of forward 5 years period of number of vessels passing through Bosphorus

\begin{tabular}{cc}
\hline Years & Number of Vessels \\
\hline $\mathbf{2 0 2 1}$ & 37,238 \\
$\mathbf{2 0 2 2}$ & 35,992 \\
$\mathbf{2 0 2 3}$ & 34,747 \\
$\mathbf{2 0 2 4}$ & 33,501 \\
$\mathbf{2 0 2 5}$ & 32,255 \\
\hline
\end{tabular}




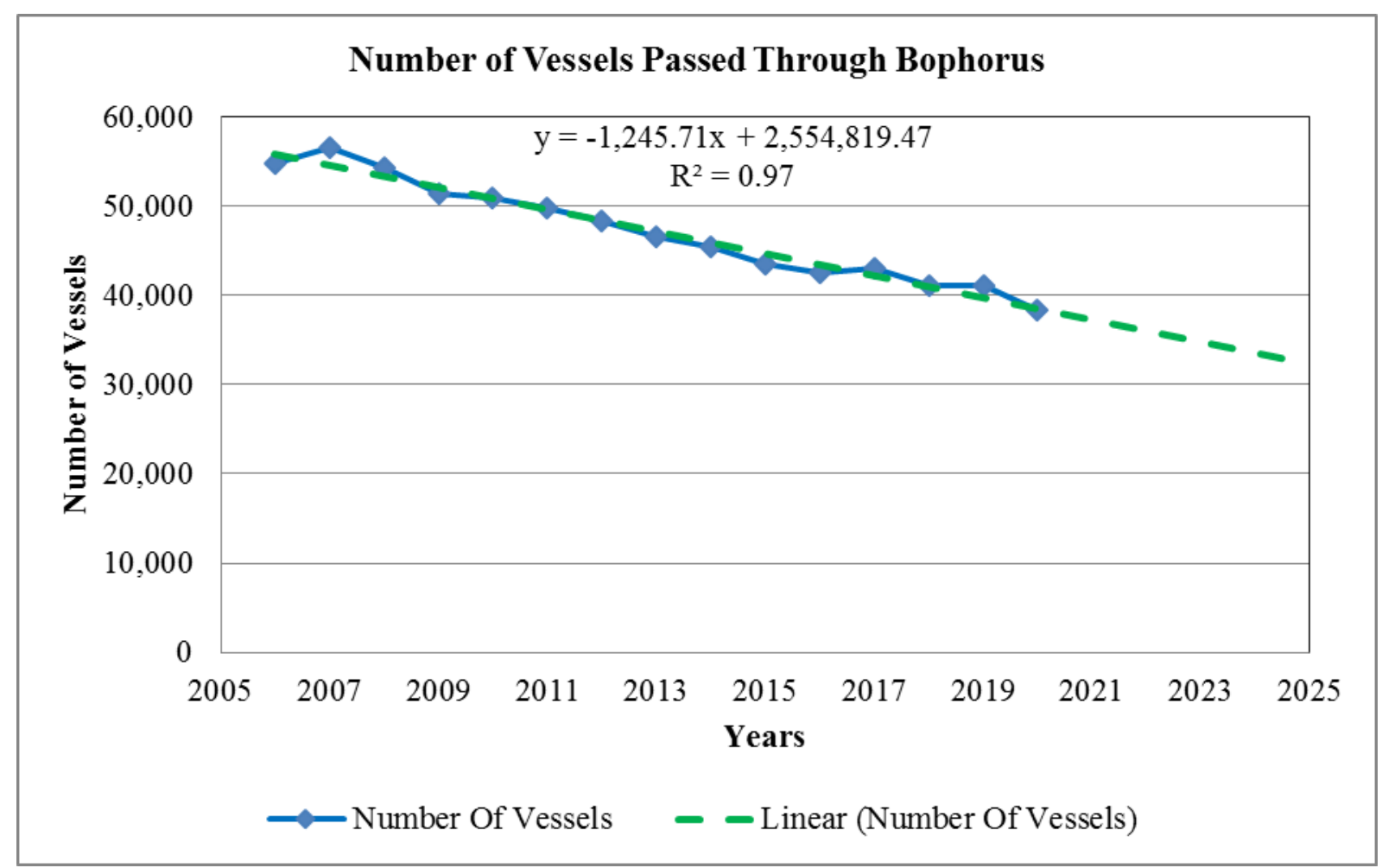

Fig. 4. Number of vessels passing through Bosphorus

The total gross tonnage (GT) data of vessels passed through Bosphorus have been analyzed by linear regression between years 2006 and 2020 (Fig. 5). The coefficient of determination value is calculated as $94.34 \%$. Thus the linear regression line can be used to estimate forward 5 years period. The estimation shows that $684,862,096$ total gross tonnage will pass through Bosphorus in year 2025 (Table 6).

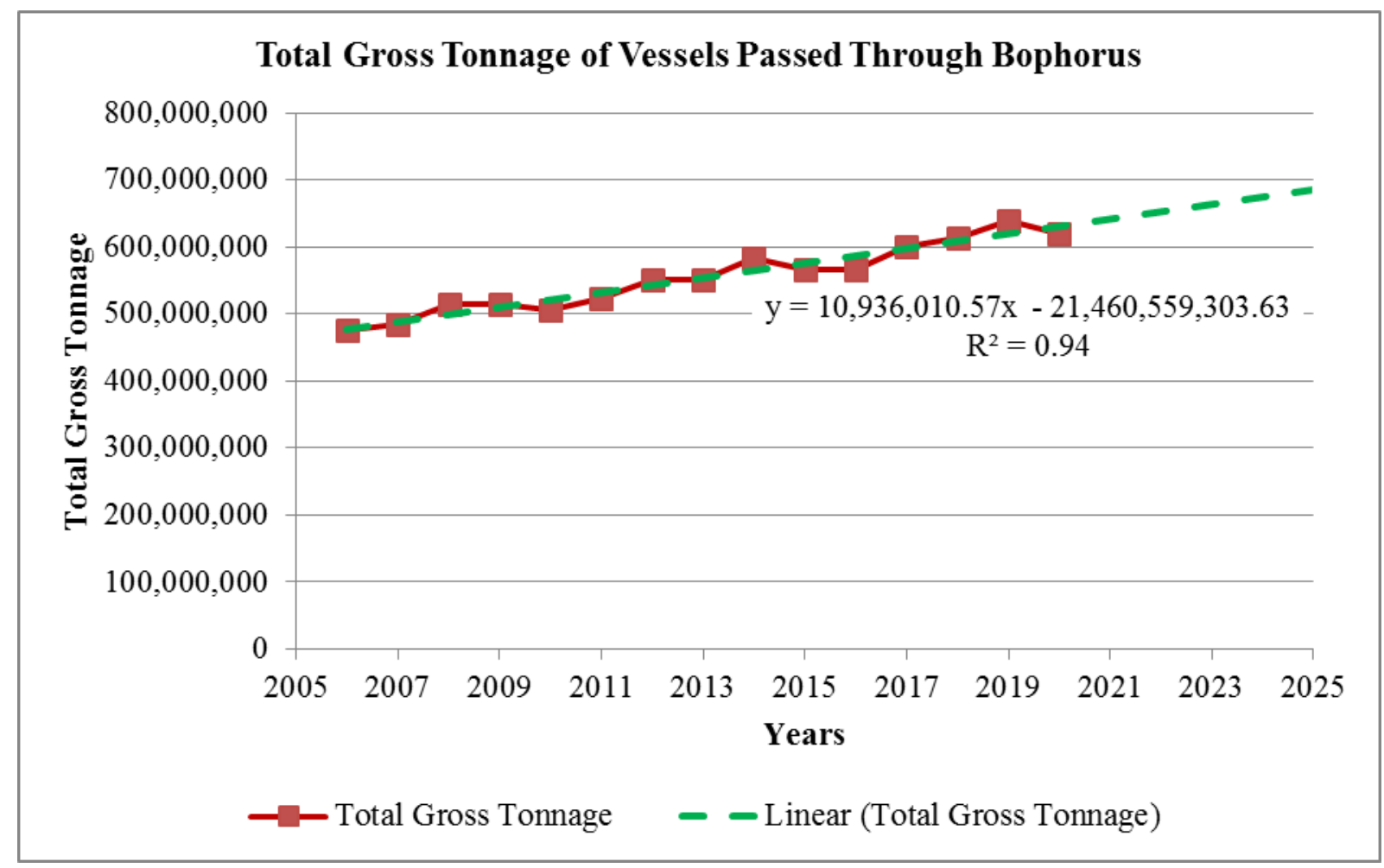

Fig. 5. Total gross tonnage of vessels passing through Bosphorus 
Table 6. Estimation of forward 5 years period of total gross tonnage of vessels passing through Bosphorus

\begin{tabular}{cc}
\hline Years & Total Gross Tonnage of Vessels \\
\hline $\mathbf{2 0 2 1}$ & $641,118,054$ \\
$\mathbf{2 0 2 2}$ & $652,054,065$ \\
$\mathbf{2 0 2 3}$ & $662,990,075$ \\
$\mathbf{2 0 2 4}$ & $673,926,086$ \\
$\mathbf{2 0 2 5}$ & $684,862,096$ \\
\hline
\end{tabular}

The gross tonnage per vessel has been calculated by dividing total gross tonnage to number of vessels (Fig. 6) and the estimation show that 18,582 gross tonnages per vessel will pass through Bosphorus in year 2025 (Table 7).

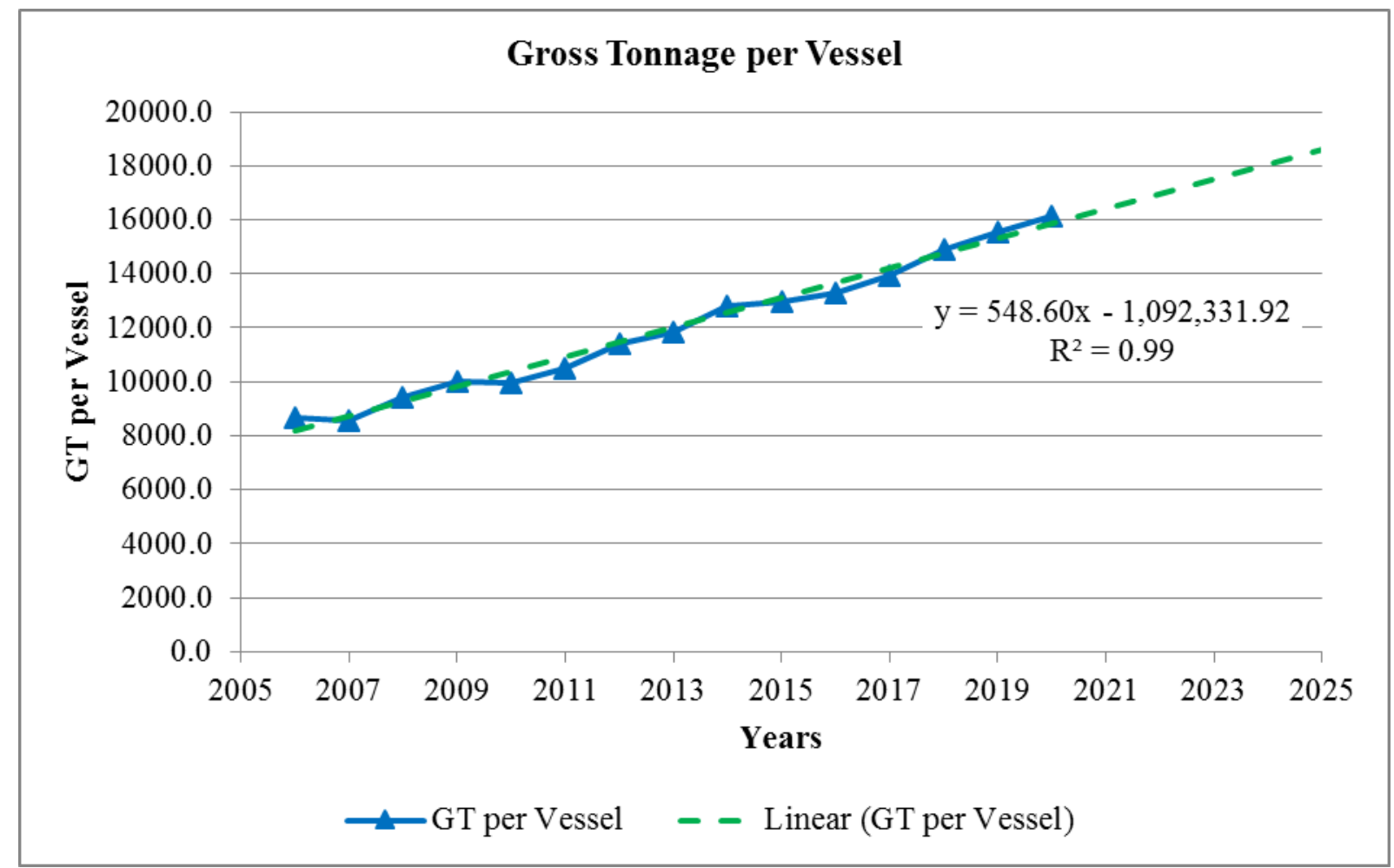

Fig. 6. Total gross tonnage per vessel passing through Bosphorus

Table 7. Estimation of forward 5 years period of total gross tonnage per vessel passing through Bosphorus

\begin{tabular}{cc}
\hline Years & Total Gross Tonnage per Vessels \\
\hline $\mathbf{2 0 2 1}$ & 16,388 \\
$\mathbf{2 0 2 2}$ & 16,936 \\
$\mathbf{2 0 2 3}$ & 17,485 \\
$\mathbf{2 0 2 4}$ & 18,034 \\
$\mathbf{2 0 2 5}$ & 18,582 \\
\hline
\end{tabular}

The data of number of vessels according to vessel type (Table 4) has been analyzed and selected results of regression analysis considering the coefficient of determination, have been given below. Vessel type of bulk carrier have been analyzed by linear regression between years 2006 
and 2020 (Fig. 7). The coefficient of determination value is $94.05 \%$. Thus the linear regression line can be used to project for 5 years. The estimation show that 10,103 bulk carrier type vessels will pass the Istanbul Strait in year 2025 (Table 8).

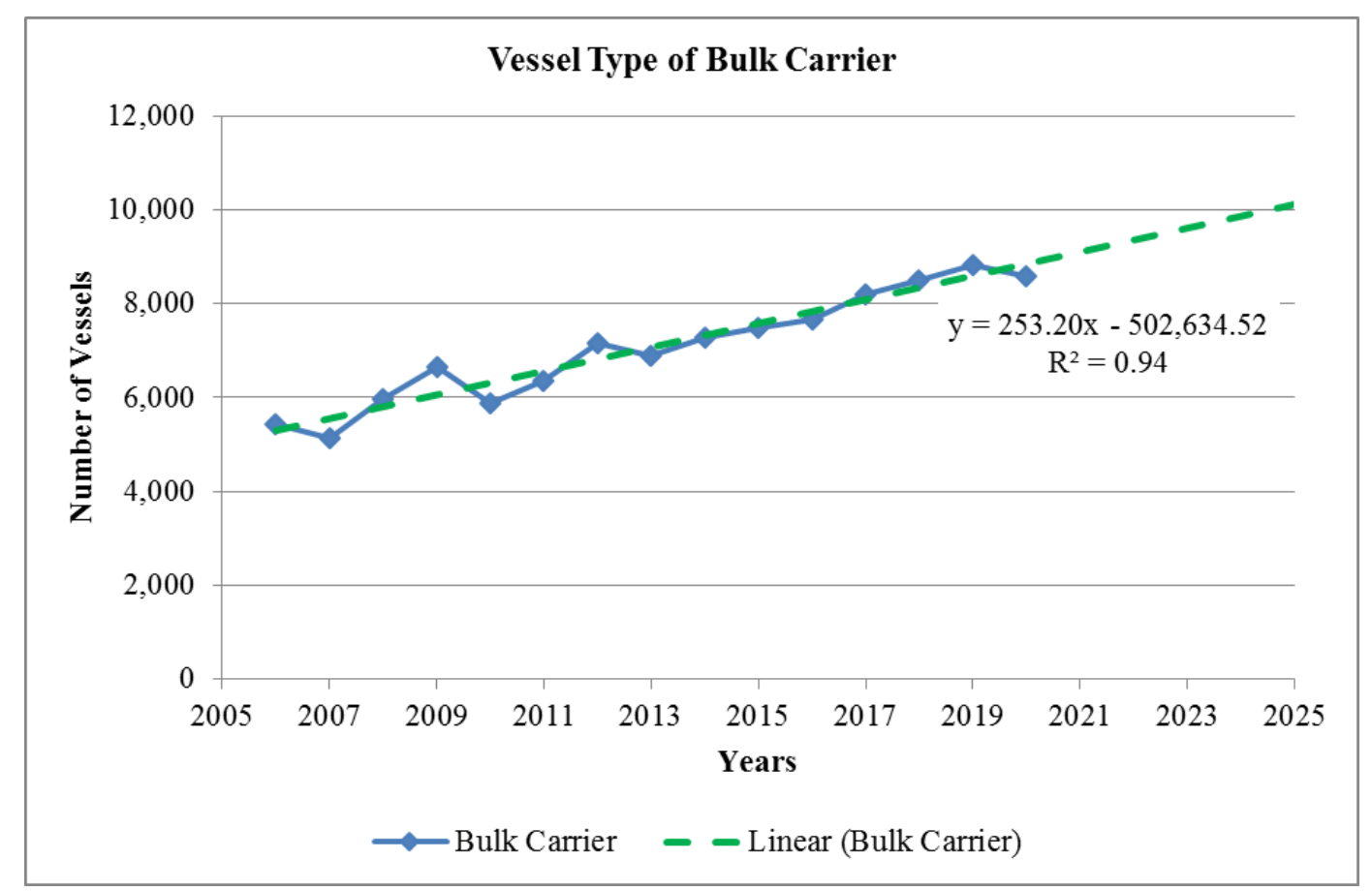

Fig. 7. Number of bulk carrier vessel type passing through Bosphorus

Table 8. Estimation of forward 5 years period of number of bulk carrier vessel type

\begin{tabular}{lc}
\hline Years & Bulk Carrier Vessel Type \\
\hline $\mathbf{2 0 2 1}$ & 9,090 \\
$\mathbf{2 0 2 2}$ & 9,343 \\
$\mathbf{2 0 2 3}$ & 9,596 \\
$\mathbf{2 0 2 4}$ & 9,850 \\
$\mathbf{2 0 2 5}$ & 10,103 \\
\hline
\end{tabular}

Vessel type of general cargo have been analyzed by linear regression between the years 2006 and 2020 (Fig. 8). The coefficient of determination value is calculated as $98.11 \%$. Thus the linear regression line can be used to estimate forward 5 years period. The estimation show that 10,356 general cargo type vessels will pass through Bosphorus in year 2025 (Table 9). 


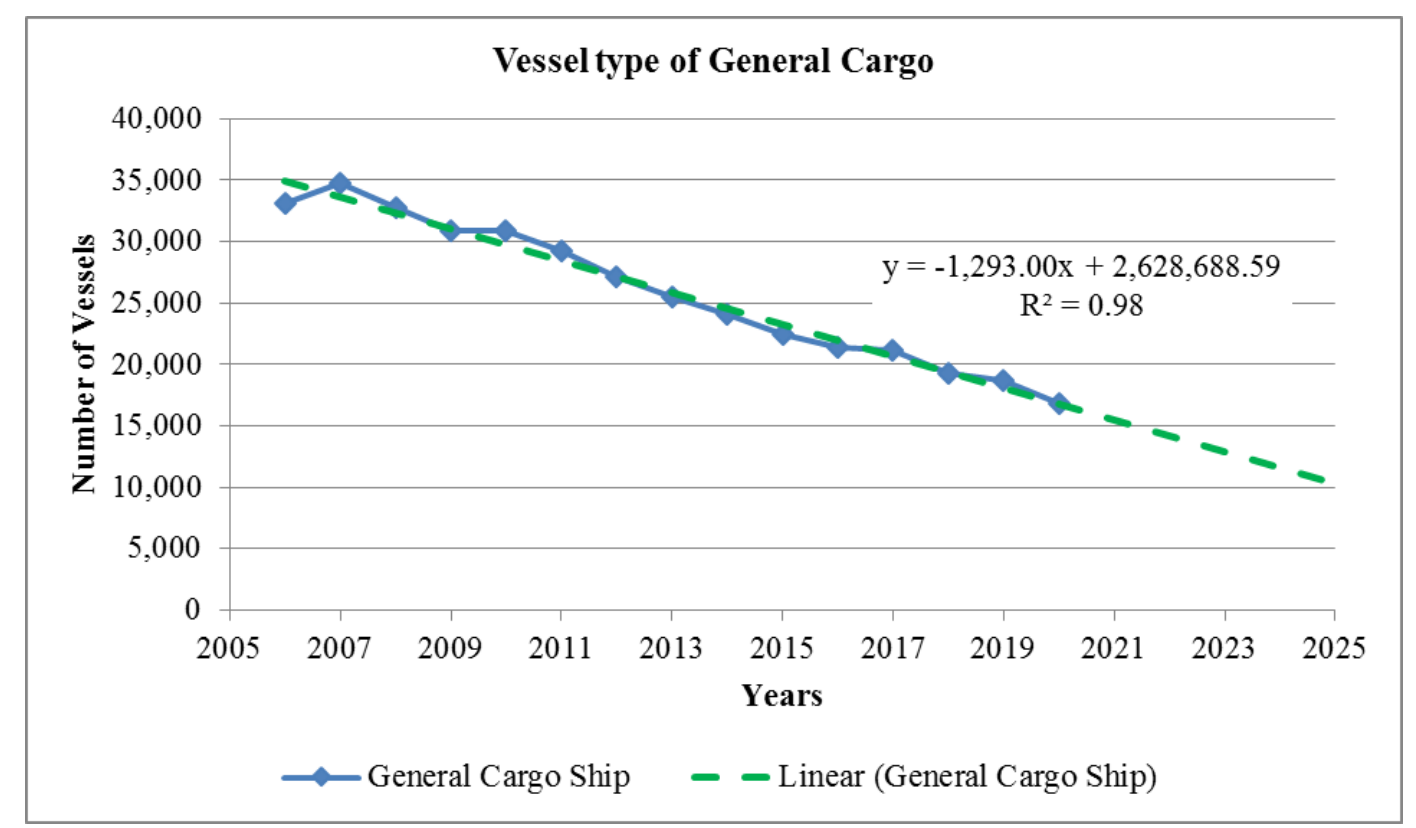

Fig. 8. Number of general cargo vessel type passing through Bosphorus

Table 9. Estimation of forward 5 years period of number of general cargo vessel type

\begin{tabular}{cc}
\hline Years & General Cargo Vessel Type \\
\hline $\mathbf{2 0 2 1}$ & 15,528 \\
$\mathbf{2 0 2 2}$ & 14,235 \\
$\mathbf{2 0 2 3}$ & 12,942 \\
$\mathbf{2 0 2 4}$ & 11,649 \\
$\mathbf{2 0 2 5}$ & 10,356 \\
\hline
\end{tabular}

Number of vessel type of livestock carrier passed through Bosphorus have been analyzed by linear regression between the years 2006 and 2020 (Fig. 9).

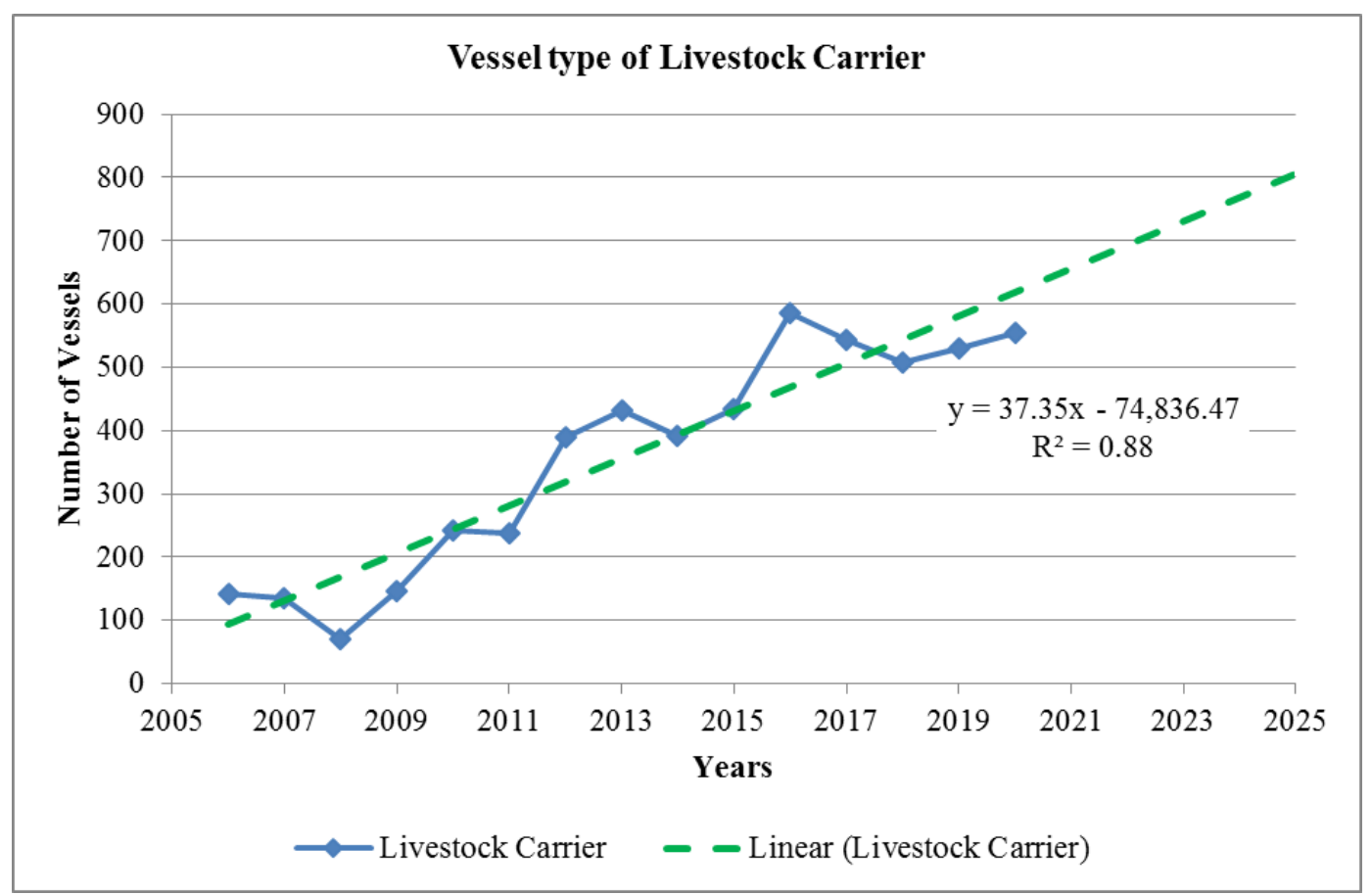

Fig. 9. Number of livestock carrier vessel type passing through Bosphorus 
The coefficient of determination value is $88.43 \%$. Thus the regression line can be used to estimate forward 5 years period. The estimation show that 805 livestock carrier ship type vessels will pass in the year 2025 (Table 10).

Table 10. Estimation of forward 5 years period of number of livestock carrier vessel type

\begin{tabular}{cc}
\hline Years & Livestock Carrier Vessel Type \\
\hline $\mathbf{2 0 2 1}$ & 655 \\
$\mathbf{2 0 2 2}$ & 692 \\
$\mathbf{2 0 2 3}$ & 730 \\
$\mathbf{2 0 2 4}$ & 767 \\
$\mathbf{2 0 2 5}$ & 805 \\
\hline
\end{tabular}

Number of passenger ship vessels have been analyzed by second order polynomial regression between the years 2006 and 2020 (Fig. 10). The coefficient of determination value is calculated as $88.02 \%$. Thus the polynomial regression line can be used to estimate forward 5 years period. The estimation show that 733 passenger ship type vessels will pass through Bosphorus in 2025 (Table 11).

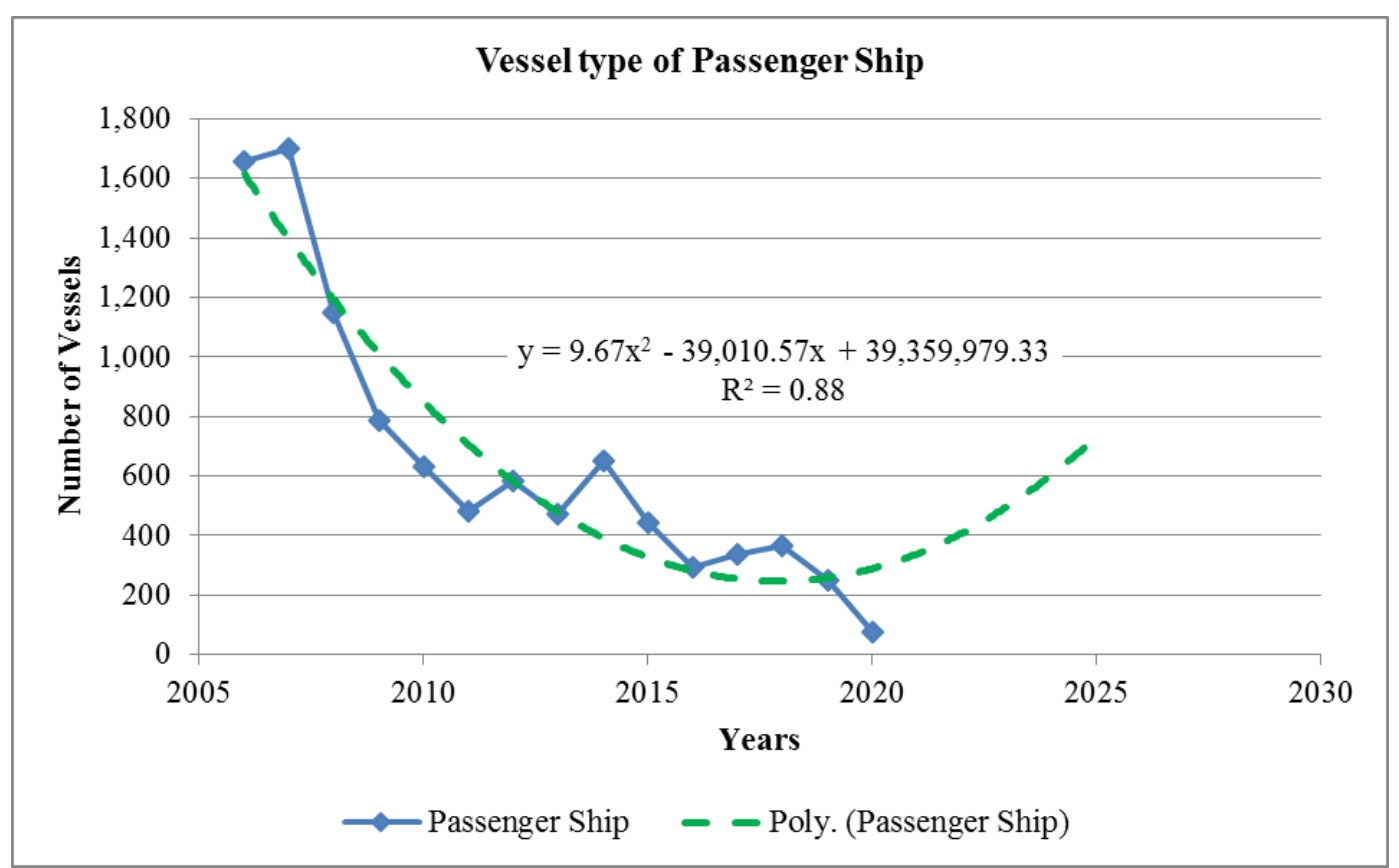

Fig. 10. Number of passenger ship vessel type passing through Bosphorus

Table 11. Estimation of forward 5 years period of number of passenger ship vessel type

\begin{tabular}{lc}
\hline Years & Passenger Ship Vessel Type \\
\hline $\mathbf{2 0 2 1}$ & 338 \\
$\mathbf{2 0 2 2}$ & 408 \\
$\mathbf{2 0 2 3}$ & 497 \\
$\mathbf{2 0 2 4}$ & 605 \\
$\mathbf{2 0 2 5}$ & 733 \\
\hline
\end{tabular}


Number of refrigerated cargo carrier vessel type have been analyzed by second order polynomial regression between the years 2006 and 2020 (Fig. 11). The coefficient of determination value is calculated as $96.40 \%$. Thus the polynomial regression line can be used to estimate forward 5 years period. The estimation show that 274 refrigerated cargo carrier vessels will pass through Bosphorus for the year 2025 (Table 12).

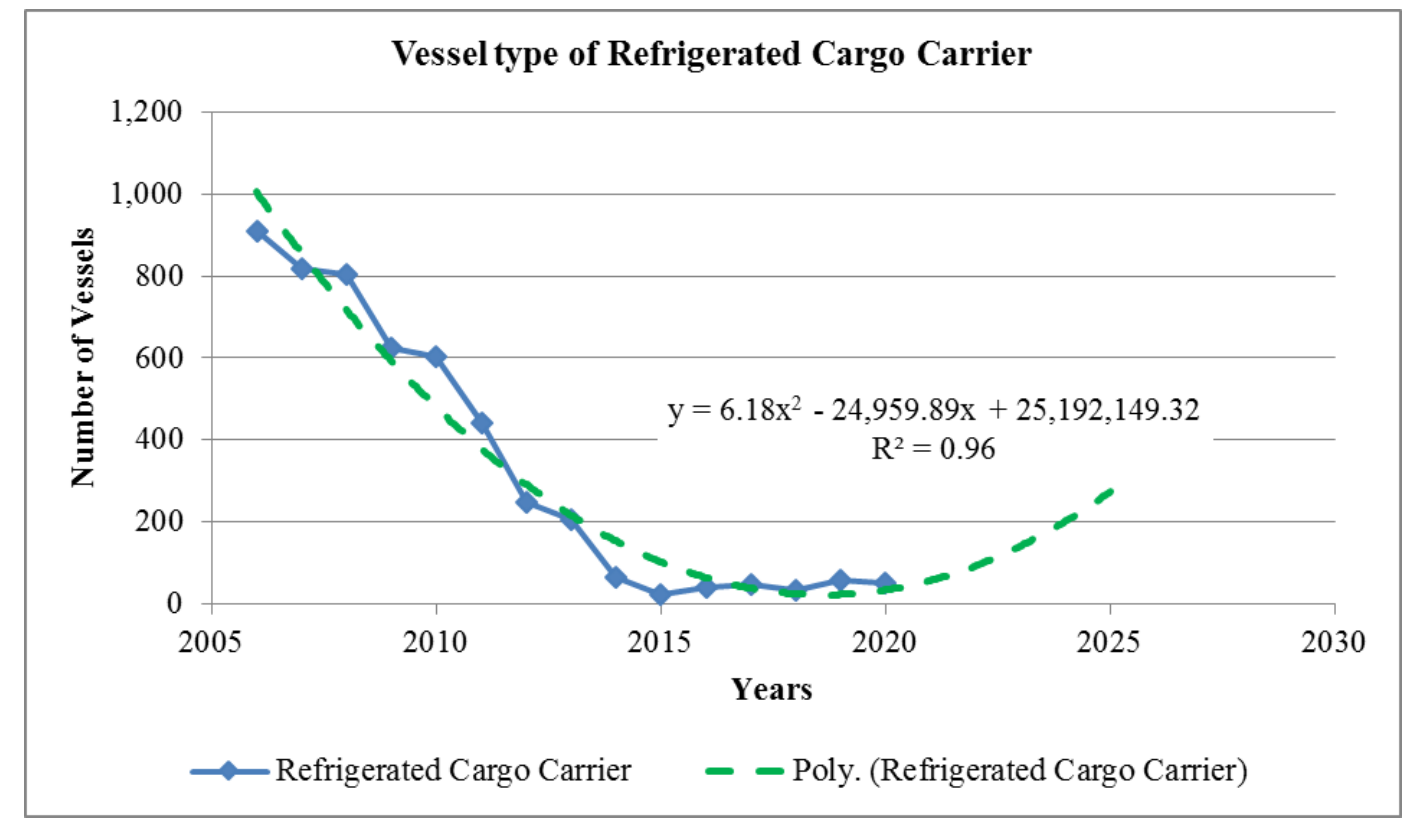

Fig. 11. Number of refrigerated cargo carrier vessel type passing through Bosphorus

Table 12. Estimation of forward 5 years period of number of refrigerated cargo carrier vessel type

\begin{tabular}{cc}
\hline Years & $\begin{array}{c}\text { Refrigerated Cargo Carrier Vessel } \\
\text { Type }\end{array}$ \\
\hline $\mathbf{2 0 2 1}$ & 57 \\
$\mathbf{2 0 2 2}$ & 93 \\
$\mathbf{2 0 2 3}$ & 141 \\
$\mathbf{2 0 2 4}$ & 201 \\
$\mathbf{2 0 2 5}$ & 274 \\
\hline
\end{tabular}

\section{Conclusions}

The data of Ministry of Transport and Infrastructure, General Directorate of Marine between the years 1995 and 2020 has been used to estimate the change of the number of vessels in the future years. Although the estimation show that the number of vessels passed through Bosphorus will decrease in the future years (Fig. 4, Table 5), the total gross tonnage will increase (Fig. 5, Table 6). Furthermore, the gross tonnage per vessel will also increase in the future (Fig. 6, Table 7).

The data of number of vessels according to vessel type (Table 4) has been analyzed and selected projectable results of regression analysis have been given in this study. The estimation results show that the number of bulk carrier vessel type (Fig. 7, Table 8), the number of livestock carrier vessel type (Fig. 9, Table 10), the number of passenger ship vessel type (Fig. 10, Table 11) and the number of refrigerated cargo carrier vessel type (Fig. 11, Table 12) will increase in 
the future. However, the number of general cargo vessel type (Fig. 8, Table 9) will decrease in the future years.

It is expected that these estimations will be apply with a high degree of accuracy if present conditions in the region will continue. These conditions may include international trade, economy, maritime transport, local regulations...etc. In order to improve the estimations all influencing variables should be study. More precise estimations can be made with statistical models.

\section{Notations}

$\begin{array}{ll}m & \text { Meter } \\ \text { Btw. } & \text { Between } \\ y & \text { Dependent variable of the data } \\ x & \text { Independent variable of the data } \\ a_{1} & \text { Slope } \\ a_{0} & \text { Constant } \\ \bar{y} & \text { Mean value of the data } \mathrm{y} \\ \bar{x} & \text { Mean value of the data } \mathrm{x} \\ R^{2} & \text { Coefficient of determination } \\ G T & \text { Gross Tonnage }\end{array}$

\section{References}

[1] Küçükosmanoğlu, A., Maritime accidents forecast model for Bosphorus, PhD Thesis, Middle East Technical University, Ankara, Turkey, 2012.

[2] WEB, https://denizcilikistatistikleri.uab.gov.tr/turk-bogazlari-gemi-gecis-istatistikleri, (10.04.2021).

[3] Atasoy, C., İstanbul Boğaz'nnda Yerel Trafiğin İncelenmesi, Yüksek Lisans Tezi, İstanbul Teknik Üniversitesi Fen Bilimleri Enstitüsü, İstanbul, Turkey, 2008.

[4] Kodak, G., Acarer, T., İstanbul Boğazı'nda deniz trafik düzenlemelerinin kaza oranına etkisinin değerlendirmesi, Aquatic Research, 4(2), 181-207, 2021.

[5] İstikbal, C., Strait of Istanbul, major accidents and abolishment of left-hand side navigation, Aquatic Research, 3(1), 40-65, 2020.

[6] Altan, Y.C., Otay, E.N., Maritime traffic analysis of the strait of Istanbul based on AIS data, The Journal of Navigation, 70, 1367-1382, 2017.

[7] Özbaş, B., Or, İ., Uluscu, O.S., Altıok, T., Simulation based risk analysis study of maritime traffic in the Strait of Istanbul, TRANSNAV, International Journal on Marine Navigation and Safety of Sea Transportation, 3(3), 295-300, 2009.

[8] Ulusçu, Ö., Özbaş, B., Altıok, T., Or, İ., Risk analysis of the vessel traffic in the strait of Istanbul, Risk Analysis, 29(10), 1454-1472, 2009. 
[9] Korçak, M., Balas, C.E., Reducing the probability for the collision of ships by changing the passage schedule in Istanbul Strait, International Journal of Disaster Risk Reduction, 48, 101593, 2020.

[10] Gümüşay, M.U., Web-Based GIS for Safe Shipping in Istanbul Bosphorus Strait, Technical Gazette, 25(2), 316-324, 2018.

[11] Başaraner, M., Yücel, M.A., Özmen, Ç., İstanbul Boğazı'nda Transit Gemilerin Kullandığı Seyir Rotalarının Coğrafi Bilgi Sistemi Yardımıyla İncelenmesi ve İyileştirilmesi. HKM Jeodezi, Jeoinformasyon ve Arazi Yönetimi Dergisi, 104 (Special Issue 2), 2011.

[12] Uğurlu, Ö., Erol, S., Başar, E., The analysis of life safety and economic loss in marine accidents occurring in the Turkish straits. Maritime Policy \& Management, 43(3), 356$370,2016$.

[13] Chapra, S.C., Canale, R.P., Numerical Methods for Engineers, McGrraw-Hill Companies, $6^{\text {th }}$ edition, 2010. 